\title{
PROSEDUR KEGIATAN BISNIS PERIKANAN KAPAL MOTOR PELITA JAYA BIDANG USAHA PENANGKAPAN IKAN DI JALUR PERAIRAN SELAT MAKASSAR
}

\author{
Destian Makbul Abdul Rozzak \\ Magister Ilmu Hukum Fakultas Hukum Universitas Jenderal Soedirman
}

\begin{abstract}
This study aims to determine the operational procedures and constraints faced Pelita Jaya Motor Vessel fishing in running a business as well as to analyze the efforts made businessman Pelita Jaya Motor Ship in reducing business losses Waterways fishing in the Makassar Strait. The research method in this thesis using sociological juridical approach. Operational procedures and constraints faced by Pelita Jaya Motor Vessel is associated with the management of the vessel licensing documents to process the fish auction at the Port of Pekalongan TPI. The constraints faced in doing business of fishing, among others, is a complex permitting process and run through many agencies. Efforts made entrepreneur Motor Vessel Pelita Jaya in reducing losses fishing business on track Makassar Strait is to make buying and selling in the middle of the sea, sell by way of joint operations, fish auctioning gradually, the company sells fish and fish processing into fish salty.
\end{abstract}

Keywords: operational procedures, business fishery, fishing.

\begin{abstract}
Abstrak
Penelitian ini bertujuan untuk mengetahui prosedur operasional dan kendala yang dihadapi Kapal Motor Pelita Jaya didalam menjalankan bisnis penangkapan ikan serta menganalisis upaya yang dilakukan pengusaha Kapal Motor Pelita Jaya didalam mengurangi kerugian bisnis penangkapan ikan di Jalur Perairan Selat Makassar. Metode penelitian dalam penulisan tesis ini menggunakan pendekatan yuridis sosiologis. Prosedur operasional serta kendala yang dihadapi Kapal Motor Pelita Jaya yaitu terkait dengan kepengurusan dokumen perizinan kapal sampai proses pelelangan ikan di TPI Pelabuhan Kota Pekalongan. Adapun kendala yang dihadapi dalam melakukan bisnis penangkapan ikan antara lain adalah proses perijinan yang rumit dan melawati banyak instansi. Upaya yang dilakukan pengusaha Kapal Motor Pelita Jaya di dalam mengurangi kerugian bisnis penangkapan ikan di jalur perairan Selat Makassar adalah dengan melakukan transaksi jual beli di tengah laut, menjual dengan cara join operasional, melelang ikan secara bertahap, menjual ikan kepada perusahaan dan mengolah ikan menjadi ikan asin.
\end{abstract}

Kata kunci: prosedur operasional, bisnis perikanan, penangkapan ikan.

\section{Pendahuluan}

Sumberdaya ikan sebagai bagian dari kekayaan alam merupakan modal dasar pembangunan nasional yang perlu dimanfaaatkan secara optimal untuk kemakmuran rakyat indonesia, dengan mengusahakannya secara berdaya guna dan berdaya hasil. Pasal 1 angka (1) Undang-undang Nomor 45 Tahun 2009 Tentang Perubahan Atas Undang-undang Nomor 31 Tahun 2004 tentang Perikanan menyebutkan bahwa "Perikanan adalah semua kegiatan yang berhubungan dengan pengelolaan dan pemanfaatan sumber daya ikan dan lingkungannya mulai dari praproduksi, produksi, pengolahan sampai dengan pemasaran yang dilaksanakan dalam suatu sistem bisnis perikanan."

Bisnis perikanan adalah semua usaha perorangan atau badan hukum untuk menangkap atau membudidayakan ikan, termasuk kegiatan menyimpan, mendinginkan atau mengawetkan ikan untuk tujuan komersial. ${ }^{1}$ Pengelolaan sumberdaya ikan yang benar pada dasarnya bentuk dari pelaksanaan amanat Undangundang Dasar 1945 dan diatur lebih lanjut dalam Undang-undang Nomor 31 Tahun 2004 tentang Perikanan dan Undang-undang Nomor

\footnotetext{
1 Kamus Hukum, 2008, Citra Umbara, Bandung, hlm 505.
} 
5 Tahun 1983 tentang Zona Ekonomi Eksklusif Indonesia (ZEEI). Berdasarkan Pasal 6 Undangundang Nomor 45 Tahun 2009 Tentang Perubahan Atas Undang-undang Nomor 31 Tahun 2004 tentang Perikanan yang berbunyi "Pengelolaan perikanan dalam wilayah pengelolaan perikanan Republik Indonesia dilakukan untuk tercapainya manfaat yang optimal dan berkelanjutan, serta terjaminnya kelestarian sumber daya ikan".

Pasal 1 angka (9) Undang-undang Nomor 45 Tahun 2009 Tentang Perubahan Atas Undang-undang Nomor 31 Tahun 2004 tentang Perikanan menyebutkan bahwa "Kapal Perikanan adalah kapal, perahu, atau alat apung lain yang digunakan untuk melakukan penangkapan ikan, mendukung operasi penangkapan ikan, pembudidayaan ikan, pengangkutan ikan, pengolahan ikan, pelatihan perikanan, dan penelitian/eksplorasi perikanan".

Terdapat berbagai jenis kapal yang beroperasi di Kota Pekalongan, mulai dari kapal-kapal kecil yang memiliki trip melaut 1-14 hari hingga kapal-kapal besar yang jalur penangkapan ikan di ZEEI yang umumnya trip melaut hingga 6 bulan lamanya. Berdasarkan prasurvei yang telah dilakukan peneliti, Kapal Motor Pelita Jaya adalah jenis kapal Purse seine dengan wilayah penangkapan ikan di perairan Selat Makassar dengan lama trip 3-6 bulan melaut. Selama itu nelayan berpisah dengan keluarga selama berbulan-bulan tetapi tidak jarang pendapatan mereka dibawah upah minimum regional kerena penghasilan nelayan menggunakan sistem bagi hasil dengan pengusaha (pemodal) sehingga banyak faktor yang mempengaruhi jumlah upah yang mereka terima, yaitu jumlah tangkapan ikan, harga ikan dipasaran, jumlah perbekalan, perizinan, potongan pungutan ketika proses jual beli dan lain-lain. ${ }^{2}$

Bisnis penangkapan ikan Kapal Motor Pelita Jaya di dalam pengoperasiannya tentunya tidak terlepas dan saling berhubungan dengan bidang model usaha lainnya yang saling berkaitan seperti, pabrik es balok, Stasiun Pengi-

2 Berdasarkan Hasil Wawancara Dengan Ade Hidayat Pengurus Kapal Motor Pelita Jaya Pada Tanggal 17 Oktober 2013. sian Bahan Bakar Nelayan (SPBN), dock kapal (bengkel kapal), usaha perbaikan jaring, toko onderdil kapal, jasa tukang pembuat pesanan kapal yang tersebar disekitar dermaga Kota Pekalongan dan lain sebagainya.

Berdasarkan hal diatas, ternyata di dalam menjalankan usaha bisnis perikanan di Kota Pekalongan terdapat berbagai macam permasalahan yang timbul, salah satunya adalah masalah pengurusan izin yang harus melalui banyak instansi dengan prosedur yang rumit dan mahal. Sehingga timbulah berbagai macam pungutan-pungutan guna memperlancar penerbitan izin usaha penangkapan ikan.

Nelayan di Kota Pekalongan sendiri tergabung dalam keanggotaan Dewan Perwakilan Cabang Himpunan Nelayan Seluruh Indonesia (DPC HNSI) Kota Pekalongan, HNSI adalah sebuah lembaga yang dalam pembentukannya termuat dalam lembaran negara dengan SK Presiden Nomor SK/01/1971 resmi berdiri secara nasional pada tanggal 21 Mei 1973. Melalui HNSI nelayan-nelayan seluruh indonesia dapat berkoordinir antara satu dan lain, HNSI sendiri memiliki tugas dan wewenang yang penting bagi masyarakat nelayan antara lain memberikan jaminan perlindungan terhadap nelayan yang menjadi anggotanya dan membantu menjamin kesejahteraan nelayan melalui koperasi yang dibentuknya yaitu KUD Makaryo mino. Pembentukan KUD Makaryo mino merupakan bentuk implementasi dari Pasal 15 ayat (1) dan (2) Undang-undang 16 Tahun 1964 Tentang Bagi Hasil Perikanan.

Kota Pekalongan memiliki fasilitas tempat pelelangan ikan yang cukup besar di wilayah Jawa tengah. Penyediaan fasilitas Tempat Pelelangan Ikan (TPI) oleh Pemerintah Daerah Kota Pekalongan memberikan pemasukan bagi kas daerah. Pemasukan berasal dari pungutan retribusi yang cukup tinggi yang dikenakan kepada orang-orang yang melakukan transaksi jual beli di Tempat Pelelangan Ikan (TPI) yaitu bakul ikan dan nelayan, namun berdasarkan prasurvei yang telah dilakukan peneliti, terdapat permasalahan lain yang dialami oleh pelaku bisnis penangkapan ikan di Kota Pekalongan. Hal tersebut terlihat pada kurang seriusnya Pemda 
untuk mengelola keamanan dan kenyamanan Tempat Pelelangan Ikan (TPI) sebagai wadah kelembagaan yang berfungsi untuk menstabilkan harga, memberikan informasi yang terbuka dan bagi penjual maupun pembeli, penyediaan data produksi perikanan. ${ }^{3}$

Kegiatan bisnis penangkapan ikan merupakan prospek yang baik bagi para pelaku usaha dibidang penangkapan ikan. Dalam kegiatan tersebut pendapatan keuntungan secara finansial menjadi sangat penting sebagai tolak ukur keberhasilan usaha yang telah dilakukan, sehingga unsur biaya sebagai modal dasar didalam menjalankan bisnis penangkapan ikan penting untuk menentukan keuntungan atau kerugian yang nantinya akan didapat oleh pelaku bisnis penangkapan ikan itu sendiri. Menurut Mulyadi, biaya adalah pengorbanan sumber ekonomi yang diukur dalam satuan uang yang telah terjadi atau yang kemungkinan akan terjadi untuk tujuan tertentu. ${ }^{4}$

Mengetahui hal tersebut diatas, berbagai macam tindakan antisipasi dalam rangka untuk mengetahui besarnya keuntungan atau kerugian dari usaha perikanan yang akan dikelola. Logikanya adalah sebuah usaha dinyatakan untung apabila nilai penerimaan lebih besar daripada total pengeluaran untuk memperbaiki dan meningkatkan keuntungan juga dapat dilakukan.

Proses untuk mendapatkan keuntungan maka nelayan harus mencari lokasi-lokasi yang terdapat populasi ikan layak untuk ditangkap di perairan Indonesia sesuai dengan jalur yang terdapat dalam SIPI. Kapal motor Pelita Jaya adalah jenis kapal purse seine dengan ukuran 81 GT penggerak utamanya adalah Motor berkapasitas 300 PK bidikannya adalah ikan pelagis kecil. Patut diketahui bahwa didaerah-derah terpencil sekitar perairan Selat Makassar masih banyak kapal tradisional milik warga lokal yang penggerak utamanya adalah layar.

hal yang sederhana ini dapat mengakibatkan sentimen antara nelayan pendatang dan

3 Berdasarkan Hasil Wawancara dengan Ari Susanto Staf Keuangan Kasir Bayar Nelayan Tempat Pelelangan Ikan (TPI) Pelabuhan Kota Pekalongan Pada Tanggal 15 Oktober 2013.

4 Mulyadi, 2002, Akuntansi Biaya, Edisi Ke-5, Aditya Media, Yogyakarta, hlm 8. nelayan lokal, sentimen semacam ini tidak terjadi antara kapal motor dan kapal tradisional saja tetapi sesama kapal purse seine. Akibatnya adalah ketika kapal pendatang menangkap ikan disebuah spot penangkapan dan mendapatkan hasil yang melimpah maka tak jarang hasil tangkapan tersebut harus dijual kepada kapal nelayan setempat (nelayan lokal). Transaksi ini terjadi di tengah laut dengan harga pembelian ikan sangat murah, hal semacam ini dianggap lazim dan menjadi kebiasaan. Kebiasaan yang dimaksud adalah kebiasaan yang mempunyai daya paksa atau yang bersifat hukum dan yang berhadapan dengan hukum undang-undang (wettenrecht). ${ }^{5}$

Kebiasaan merupakan norma yang keberadaannya dalam masyarakat diterima sebagai aturan yang mengikat walaupun tidak ditetapkan oleh pemerintah. Kebiasaan adalah tingkah laku dalam masyarakat yang dilakukan berulangulang mengenai sesuatu hal yang sama, yang dianggap sebagai aturan hidup. Kebiasaan dalam masyarakat sering disamakan dengan adat istiadat. Berkaitan dengan hal ini Bronislaw Malinowski, menyatakan bahwa perbedaan antara kebiasaan dengan hukum adat didasarkan pada dua kriteria, yakni sumber sanksinya dan pelaksanaannya. Pada kebiasaan, sumber sanksi dan pelaksanaannya adalah para warga masyarakat secara individuil atau kelompok, sedangkan pada hukum adat, maka sumber sanksi dan pelaksanaannya adalah suatu kekuasaan terpusat atau badan-badan tertentu di dalam masyarakat. ${ }^{6}$

Berkaitan dengan kebiasaan dan adat Istiadat terdapat beberapa isu kritis perihal pengelolaan perikanan, antara lain konflik antar nelayan, penangkapan ikan berlebih (over fishing) dan penggunaan alat tangkap yang tidak berwawasan lingkungan. Berdasarkan $\mathrm{Pa}-$ sal 2 ayat (2) huruf (c) Peraturan Pemerintah Nomor 60 Tahun 2007 Tentang Konservasi Sumber Daya Ikan menyebutkan bahwa konservasi sumber daya ikan dilakukan berdasarkan prinsip pertimbangan kearifan lokal,

5 Dominikus Rato, 2009, Pengantar Hukum Adat, LaksBang Pressindo, Yogyakarta, hlm 5.

6 Soerjono Soekanto, 1978, Pokok-pokok Hukum Adat, Bandung, Alumni, hlm 17. 
kerena kearifan lokal terbukti sangat mampu berperan secara nyata dalam pengelolaan sumber daya ikan secara lestari diberbagai tempat di Indonesia. Hal tersebut ditegaskan pula didalam penjelasan Pasal 9 ayat (1) huruf (b) disebutkan bahwa potensi konflik kepentingan meliputi potensi konflik antar sektor, antar masyarakat, antara masyarakat dengan pemerintah, antara pemerintah dan pemerintah daerah. Potensi ancamannya meliputi potensi ancaman terhadap habitat perairan dan biotanya. Kearifan lokal merupakan norma dan kebiasaan yang berlaku pada masyarakat tertentu yang berkaitan dengan nilai-nilai pelestarian lingkungan hidup.

Salah satu contoh kebiasaan masyarakat nelayan di jalur perairan Selat Makassar yang masih berlangsung saat ini adalah perihal penjualan hasil tangkapan ikan yang diperoleh dari kapal pendatang kepada kapal nelayan setempat (nelayan lokal), hal ini dapat menyebabkan kerugian bagi pengusaha. Dari hal diatas maka secara otomatis berpengaruh terhadap masalah kesejahteraan nelayan, dimana pendapatan bersih yang diperoleh nelayan tidak menentu tergantung pada bagi hasil yang didapat dari setiap trip, dikarenakan sistem bagi hasil sendiri didalamnya terdapat klausul-klausul yang menyatakan bahwa perbekalan termasuk biaya perizinan ditanggung bersama antara pemilik kapal dan nelayan. Hal ini merupakan dampak dari biaya-biaya yang muncul diluar dari penganggaran biaya (cost budget) yang sudah ditentukan. Perilaku pengusaha yang mencari celah untuk dapat menutup biaya-biaya yang muncul diluar cost budget sehingga pada prakteknya mereka tak jarang menyimpangi peraturan perundang-undangan yang telah dibentuk oleh pemerintah, agar mampu bertahan didalam menjalankan kegiatan bisnis perikanan tangkap. ${ }^{7}$

Uraian diatas dapat diketahui kegiatan bisnis perikanan tangkap yang dilakukan oleh Kapal Motor Pelita Jaya peneliti menentukan lokasi penelitian di Kota Pekalongan dengan objek penelitian pada Kapal Motor Pelita Jaya

7 Berdasarkan Hasil Wawancara Dengan Ade Hidayat Pengurus Kapal Motor Pelita Jaya Pada Tanggal 17 Oktober 2013. jenis purse seine ukuran 81 gross ton (GT) milik Lianawaty, Dock kapal (bengkel kapal) Along Jaya, Tempat Pelelangan Ikan (TPI) Kota Pekalongan, Kantor Stasiun Pengisian Bahan Bakar Nelayan (SPBN) Slamaran, Kantor Dewan Perwakilan Cabang Himpunan Nelayan Seluruh Indonesia (DPC HNSI) Kota Pekalongan. Peneliti tertarik untuk mengangkat dan mengulas permasalahan tersebut dalam suatu bentuk tesis dengan judul "Prosedur Kegiatan Bisnis Perikanan Kapal Motor Pelita Jaya Bidang Usaha Penangkapan Ikan Di Jalur Perairan Selat Makassar".

\section{Perumusan Masalah}

Berdasarkan latar belakang masalah sebagaimana telah diuraikan di atas, maka dirumuskan permasalahan sebagai berikut: Pertama, bagaimanakah prosedur operasional serta kendala yang dihadapi Kapal Motor Pelita Jaya di dalam menjalankan bisnis penangkapan ikan di jalur perairan Selat Makassar; Kedua, bagaimanakah upaya yang dilakukan pemilik Kapal Motor Pelita Jaya di dalam mengurangi kerugian bisnis penangkapan ikan di jalur perairan Selat Makassar.

\section{Metode Penelitian}

Penelitian ini adalah penelitian kualitatif dengan pendekatan yuridis sosiologis atau social legal research. Spesifikasi penelitian deskriptif adalah suatu penelitian yang dimaksudkan untuk memberikan data seteliti mungkin dengan manusia, keadaan, atau gejala-gejala lainnya serta hanya menjelaskan keadaan obyek masalahnya tanpa bermaksud mengambil kesimpulan yang berlaku umum. ${ }^{8}$

Penelitian ini dilakukan dengan menetapkan lokasi penelitian di Kota Pekalongan. Objek penelitiannya adalah Kapal Motor Pelita Jaya jenis purse seine ukuran 81 gross ton (GT) milik Lianawaty, Dock (bengkel kapal) Along Jaya, Pelabuhan Perikanan Nusantara Pekalongan (PPNP), Tempat Pelelangan Ikan (TPI) Pelabuhan Kota Pekalongan, Kantor Stasiun Pengisian Bahan Bakar Nelayan (SPBN) Slamaran, Kantor Dewan Perwakilan Cabang Himpunan

\footnotetext{
8 Soerjono Soekamto, Loc. Cit, hIm 10.
} 
40 Jurnal Idea Hukum

Vol. 1 No. 1 Edisi Maret 2015

Magister Hukum Fakultas Hukum Universitas Jenderal Soedirman

Nelayan Seluruh Indonesia (DPC HNSI) Kota Pekalongan.

\section{Pembahasan}

Prosedur Operasional Kapal Motor Pelita Jaya di dalam menjalankan bisnis penangkapan ikan di jalur perairan Selat Makassar

Prosedur operasional Kapal Motor Pelita Jaya antara pemilik kapal dengan nelayan. Pemilik menyiapkan dokumen operasional Kapal Motor Pelita Jaya diawali dengan pengurusan SIUP, kewajiban pemilik kapal sebagai pengusaha dibidang perikanan tangkap tersebut termuat didalam ketentuan Pasal 26 Undangundang Nomor 31 Tahun 2004 Tentang Perikanan. Kepengurusan SIUP Kapal Motor Pelita Jaya diajukan kepada Direktorat Jenderal Perikanan Tangkap dengan masa berlaku izin selama 30 (tigapuluh) tahun. Perizinan selanjutnya adalah mengenai SIPI, diawali dengan pengurusan Surat Rekomendasi SIPI kepada Direktorat Jenderal Perikanan Tangkap setelah melakukan proses pemeriksaan fisik kapal dilakukan. Proses tersebut bertujuan agar mengetahui ukuran serta mesin kapal yang digunakan didalam operasional penangkapan ikan, hal tersebut berdasarkan pada ketentuan Pasal 46 ayat (3) Peraturan Menteri Kelautan dan Perikanan Nomor PER/12/MEN/2009 Tentang Perubahan Atas Peraturan Menteri Kelautan dan Perikanan Nomor PER/05/MEN/2008 Tentang Usaha Perikanan Tangkap.

SIPI dapat diterbitkan apabila pemilik kapal telah melunasi Pelunasan Pungutan Perikanan (PPP). Syarat lain yang berkaitan dengan terbitnya SIPI yaitu pemilik kapal memiliki Surat Keterangan Aktivasi Transmiter. Hal tersebut berdasarkan pada ketentuan Pasal 1 angka (5) Peraturan Menteri Kelautan dan Perikanan Nomor PER.07/MEN/2010 Tentang Surat Laik Operasi Kapal Perikanan. Masa berlaku SIPI adalah 1 (satu) tahun, dengan diterbitkannya SIPI 2tersebut maka Kapal Motor Pelita Jaya harus mendaratkan kapalnya sesuai dengan yang tercantum didalam SIPI yaitu di Pelabuhan Kota Pekalongan.

Dokumen perizinan selanjutnya adalah Buku Lapor Pangkalan, buku tersebut wajib di- miliki setiap kapal perikanan sesuai dengan $\mathrm{Pa}$ sal 2 ayat (1) Keputusan Direktur Jenderal Pengawasan dan Pengendalian Sumber Daya Kelautan dan Perikanan Nomor Kep.043/DJP2SDKP/2008 Tentang Penggunaan Buku Lapor Pangkalan Bagi Kapal Perikanan.

Kapal Motor Pelita Jaya didalam melakukan operasional diwajibkan memiliki Surat Izin Radio Laut yang terdiri dari Izin Stasiun Radio Laut yang diterbitkan oleh Departemen Telekomunikasi dan Informatika serta Surat Keterangan Radio Telekomunikasi kapal berukuran $100 \mathrm{M}^{3} \mathrm{~s} / \mathrm{d}^{850 \mathrm{M}^{3}}$ yang diterbitkan oleh Direktor Jenderal Perhubungan Laut Direktur Kenavigasian berdasarkan pada Pasal 11 Undang-undang Nomor 36 Tentang Telekomunikasi dan Peraturan Radio International Telecommunication Union (ITU) Geneva terkait ketentuan Pasal 7 Undang-undang Nomor 36 Tentang Telekomunikasi dan Peraturan Radio.

Terkait dengan kegiatan operasionalnya diperlukan izin yang berkaitan dengan kelayakan dan pengawakan kapal. Setiap kapal perikanan diwajibkan memiliki Setrifikat Kelaikan dan Pengawakan Kapal Penangkap Ikan yang diterbitkan oleh Menteri Perhubungan Direktor Jenderal Perhubungan Laut dengan masa berlaku 11 (sebelas) bulan. Hal tersebut berdasarkan pada ketentuan Pasal 2 dan 4 Keputusan Menteri Perhubungan Nomor KM.46 Tahun 1996.

Berkaitan dengan proses pengawasan terhadap terpenuhinya peraturan perundangundangan untuk menjamin keselamatan dan keamanan pelayaran maka Syahbandar menerbitkan Surat Tanda Bukti Lapor Kedatangan Kapal Perikanan. Hal tersebut berdasarkan pada Pasal 5 Peraturan Menteri Kelautan dan Perikanan Nomor 3/PerMen-KP/2013 Tentang Kesyahbandaran di Pelabuhan Perikanan.

Kapal Motor Pelita Jaya sebelum melakukan kegiatan penangkapan ikan wajib memiliki Surat Layak Operasi Kapal Perikanan, hal tersebut berdasarkan pada ketentuan Pasal 1 Peraturan Menteri Kelautan dan Perikanan Republik Indonesia Nomor Per.07/MEN/2010 Tentang Surat Layak Operasi Kapal Perikanan. SLO diterbitkan oleh Syahbandar. 
Pemilik kapal juga diwajibkan memiliki Buku Harian (Log Book) Penangkapan Ikan yang diterbitkan oleh Pelabuhan Perikanan Nusantara Pekalongan (PPNP), hal tersebut sesuai dengan ketentuan Pasal 1 angka (4) dan Pasal 5 huruf (i) Peraturan Menteri Kelautan dan Perikanan Nomor 03/PERMEN-KP/2013 Tentang Kesyahbandaran di Pelabuhan Perikanan.

Persiapan keberangkatan kapal, Nahkoda sebagai penanggung jawab atas segala tindakan dan tanggung jawab terhadap awak kapal. Hubungan hukum dimulai pada saat pemilik dan Nahkoda melakukan kesepakatan dalam bentuk satu perjanjian kerja yang tertuang didalam Buku SIJIL, hal tersebut berdasarkan pada ketentuan Pasal 376 KUH Dagang dan ketentuan Pasal 1 angka (40) Undang-undang Nomor 17 Tahun 2008 Tentang Pelayaran. Nahkoda sebagai penanggung jawab atas segala tindakan yang dilakukan diatas kapal wajib memiliki Surat Keterangan Kecakapan 60 Mill Plus, disamping itu Nahkoda juga dibantu oleh seorang motoris yang memiliki Surat Keterangan Kecakapan 60 Mill Plus yang menerangkan bahwa yang bersangkutan boleh berlayar sebagai Kepala Kamar Mesin, Nahkoda juga dibantu oleh seorang Ahi Nautika yang memiliki Sertifikat berstandar Internasional yaitu Sertifikat Ahli Nautika Kapal Penangkap Ikan III (ATKAPIN III).

Nahkoda dan ABK Pelita Jaya selanjutnya wajib melakukan pemeriksaan kesehatan melalui Departemen Kesehatan. Pemeriksaan kesehatan dapat dilakukan di Puskesmas atau Rumah Sakit terdekat yang selanjutnya akan diterbitkan Buku Kesehatan (health book).

Tahapan selanjutnya setelah dokumen perizinan terpenuhi pemilik kapal dan Nahkoda membuat kesepakatan lamanya trip yang akan ditempuh, hal tersebut bertujuan untuk menentukan jumlah perbekalan yang akan dibawa kelaut. Apabila perbekalan telah terpenuhi, Kapal Motor Pelita Jaya berangkat dari Pelabuhan Perikanan Nusantara Pekalongan (PPNP). Operasional penangkapan ikan dilakukan sesuai dengan jalur yang telah ditetapkan didalam perizinan penangkapan ikan. Berakhirnya trip perja- lanan menangkap ikan mewajibkan Kapal Motor Pelita Jaya mendaratkan ikan hasil tangkapan di pelabuhan PPNP sesuai dengan SIPI.

Bongkar muat dan penyeleksian kualitas ikan hasil tangkapan dilakukan Kapal Motor Pelita Jaya di dermaga PPNP, apabila proses tersebut telah dilalui, Kapal Motor Pelita Jaya melakukan lelang hasil tangkapan ikan di TPI Pelabuhan Kota Pekalongan. Hasil penjualan ikan melalui proses lelang akan dipotong biaya retribusi sebanyak 3\% (tiga persen), sewa basket, dan biaya bongkar ikan. Untuk selanjutnya akan dilakukan proses bagi hasil antara pemilik dan nelayan sebanyak 50\%:50\% (lima puluh persen banding lima puluh persen) sesuai dengan kesepakatan.

\section{Kendala yang Dihadapi Kapal Motor Pelita Jaya di dalam menjalankan bisnis penang- kapan ikan di jalur perairan Selat Makassar}

Kendala yang dialami yakni proses perizinan yang rumit dan melewati banyak instansi yang harus ditempuh oleh pemilik Kapal Motor Pelita Jaya. Hal ini sangat menghambat bisnis penangkapan ikan di Selat Makassar.

Pertama, perizinan Direktorat Jendral Perikanan Tangkap. Dokumen yang harus dilengkapi oleh pemilik kapal antara lain adalah Dokumen Tanda Pelunasan Pungutan Perikanan, stiker barcode, Surat Izin Penangkapan Ikan (SIPI), Surat Izin Usaha Perikanan (SIUP).

Kedua, perizinan Direktorat Jendral Pengawasan dan Pengendalian Sumber Daya Kelautan dan Perikanan. Salah satu upaya pemerintah dalam hal pemantauan kegiatan penangkapan ikan di wilayah perairan Indonesia adalah dengan cara pengaktivan transmiter atau yang disebut dengan Vessel Monitoring System (VMS). Kapal Motor Pelita Jaya wajib memiliki Surat Keterangan Aktivasi Transmiter yang dikeluarkan Oleh Direktorat Jendral Pengawasan dan Pengendalian Sumber Daya Kelautan dan Perikanan.

Ketiga, perizinan Direktorat Jenderal Pengawasan Sumberdaya Kelautan dan Perikanan. Kapal Motor Pelita Jaya wajib memiliki Buku Lapor Pangkalan yang berisi data tanggal keberangkatan dan kedatangan kapal. Hal ini 
42 Jurnal Idea Hukum

Vol. 1 No. 1 Edisi Maret 2015

Magister Hukum Fakultas Hukum Universitas Jenderal Soedirman

diawasi oleh pengawas perikanan dan perizinannya dikeluarkan oleh Direktorat Jenderal Pengawasan Sumberdaya Kelautan dan Perikanan.

Keempat, perizinan Direktorat Jenderal Perikanan Tangkap Pelabuhan Perikanan Nusantara Pekalongan. Melalui instansi ini pemilik Kapal Motor Pelita Jaya diperiksa secara fisik dan kelengkapan dokumen yang dimiliki berdasarkan peraturan perundang-undangan yang berlaku. Setelah proses ini kapal akan diberikan Surat Tanda Bukti Keberangkatan Kapal (out clearance).

Log Book Penangkapan Ikan di Indonesia, diperlukan untuk mencatat tanggal kapal menangkap ikan, posisi lintang dan bujur kapal serta lama operasi kapal di dalam menjalankan penangkapan ikan sekaligus didalamnya juga terdapat keterangan jenis ikan yang ditangkap beserta jumlahnya dalam satua kilo. Buku Sijil yang berisikan daftar Anak Buah Kapal (ABK).

Kelima, perizinan Polisi Daerah Jawa Tengah Resor Pekalongan Kota Satuan Polisi Perairan. Kapal Motor Pelita Jaya dalam hal keberangkatan kapal kelaut harus memiliki Surat Tanda Laporan Kapal Keluar dari Polisi Airut.

Keenem, perizinan Departemen Perhubungan Direktorat Jenderal Perhubungan Laut. Sertifikat Kelaikan dan dan Pengawakan Kapal Penangkap Ikan yang diterbitkan oleh Direktorat Jenderal Perhubungan Laut dengan masa berlaku selama 11 (sebelas) bulan. Surat Kelaikan dan dan Pengawakan Kapal Penangkap Ikan diterbitkan apabila Kapal Motor Pelita Jaya telah memenuhi ketentuan tentang keselamatan konstruksi, mesin, perlengkapan navigasi, alat penolong, alat pemadam kebakaran, perlengkapan radio, perlengkapan pencegahan pencemaran, dan perlengkapan penangkapan ikan lainnya berdasarkan ketentuan yang berlaku.

Kapal Motor Pelita Jaya mengurus rekomendasi Izin Stasiun Radio Kapal Laut yang nantinya akan diteruskan sebagai tembusan ke Departemen Komunikasi dan Informatika Direktorat Jenderal Pos dan Telekomunikasi untuk menerbitkan Surat Izin Stasiun Radio Kapal Laut, dengan masa berlaku izin selama 12 (dua belas) bulan. Kedua Departemen tersebut berkedudukan di Jakarta.

Ketujuh, perizinan Kantor Unit Penyelenggara Pelabuhan Kelas II Pekalongan dibawah Kementrian Perhubungan Laut. PAS Tahunan Kapal diterbitkan kepada Kapal Motor Pelita Jaya sebagai penegasan bahwa kapal tersebut merupakan kapal penangkap ikan berkebangsaan Indonesia.

Surat Keterangan Radio Telekomunikasi Kapal Berukuran $100 \mathrm{~m}^{3} \mathrm{~s} / \mathrm{d} 850 \mathrm{~m}^{3}$. Surat tersebut menerangkan bahwa Kapal Motor Pelita Jaya telah memiliki perangkat komunikasi radio yang memenuhi ketentuan yang berlaku.

Kedelapan, perizinan Departemen Kesehatan Republik Indonesia. Pengawakan Kapal Motor Pelita Jaya baik nahkoda maupun ABK Pelita Jaya dilakukan pemeriksaan kesehatan dan pemeriksaan tempat seperti dapur, ruang rakit makanan, gudang, ruang tidur $\mathrm{ABK}$, air bersih, dan bagian-bagian yang terdapat didalam kapal telah memenuhi standar kesehatan dan layak untuk digunakan.

Kesembilan, Pertamina. Kapal penangkap ikan adalah salah satu sasaran pemerintah dalam hal pemberian subsidi bahan bakar solar. Kapal Motor Pelita Jaya merupakan salah satu jenis kapal perikanan yang menggunakan bahan bakar solar bersubsidi dari pemerintah, dengan ketentuan tersebut maka Pertamina sebagai pemasok bahan bakar solar bersubsidi menerbitkan Buku Langganan Bunker BBM Bersubsidi untuk mengontrol dan mengawasi penggunaan solar bersubsidi bagi kapal perikanan yang melakukan pengisian bahan bakar solar di Stasiun Pengisian Bahan Bakar Nelayan (SPBN).

Hal tersebut diatas adalah uraian Kapal Motor Pelita Jaya didalam mengurus kelengkapan dokumen perizinan yang melewati 9 (sembilan) instansi dengan berbagai macam persyaratan administrasi yang rumit serta kedudukan Kantor yang berbeda-beda kota. Hal tersebut tentu saja memunculkan biaya tersendiri dalam hal kepengurusan dokumen serta biaya transportasi. 


\section{Retribusi VMS dan Pelunasan Pungutan Per- ikanan yang Mahal}

Masalah pembayaran VMS yang kurang transparan dimana pemilik kapal hanya membayar ke agen pembuat alat VMS dengan tanda bukti pembayaran slip pembayaran dari bank tanpa ada rincian biaya pembayaran Pajak VMS. Biaya pembayaran VMS adalah 6 juta rupiah.

Masalah lain yaitu pada Pelunasan Pungutan Perikanan (PPP) yang tinggi yaitu hingga mencapai Rp. 17.612.700,- (tujuh belas juta enam ratus dua belas ribu tujuh ratus rupiah). PPP ini adalah prasyarat untuk mendapatkan SIPI kapal, serta pengurusan kelengkapan dokumen lain. Selain itu Masa Berlaku dokumen Kapal Motor Pelita Jaya yang berjumlah kurang lebih sebanyak 17 (tujuh belas) memiliki masa berlaku yang berbeda-beda, sehingga dalam melakukan trip perjalanan menangkap ikan sering kali mengalami dokumen yang masa aktifnya berakhir ditengah perjalanan, oleh sebab itu Kapal Motor Pelita Jaya dapat terkena denda pelanggaran (tilang) oleh Polisi Airut. Kisaran denda untuk sekali tilang bisa mencapai Rp. 25.000.000,- (Dua Puluh Lima Juta Rupiah).

\section{Biaya docking Kapal yang Mahal}

Proses docking (bengkel) kapal dilakukan sebagai syarat bagi kapal penangkap ikan yang akan berangkat menangkap ikan. Syarat tersebut terkait dengan penerbitan SLO dan SIB dari Syahbandar. Kedua dokumen tersebut merupakan bagian dari dokumen yang wajib ada diatas kapal. Untuk 1 minggu kisaran biaya docking kapal yang dikeluarkan oleh pemilik Kapal Motor Pelita Jaya sebesar 20 juta hingga 25 juta.

\section{Modal Usaha yang Besar}

Modal Kapal Motor Pelita Jaya di dalam melakukan 1 trip perjalanan menangkap ikan membutuhkan modal minimal Rp.200.000.000,(Dua Ratus Juta Rupiah). Modal tersebut digunakan untuk perbekalan bahan pokok makanan, solar, oli, air tawar, es balok, garam, onderdil kapal, dan lain sebagainya.

\section{Tingginya retribusi pada saat lelang}

Retribusi yang masuk pada Pemerintah Daerah Kota Pekalongan sebesar sebesar 3\% (tiga persen) dimana 1,5\% (satu setengah persen) dikenakan kepada bakul ikan dan 1,5\% (satu setengah persen) dikenakan bagi nelayan.

Selain retribusi, nelayan juga dikenakan iuran wajib sebesar $1,5 \%$ (satu setengah persen) hingga $2 \%$ (dua persen) sesuai kesepakatan antara nelayan dengan pengelola yaitu KUD Makaryo Mino. Total biaya yang dikeluarkan oleh nelayan dalam proses pelelangan ikan sebesar 3\% (tiga persen) dari jumlah lelang diluar biaya bongkar hasil perikanan dan sewa basket ikan.

\section{Belum adanya Patokan Harga Ikan}

Sehingga terjadi harga yang amat rendah ketika musim ikan dan harga yang melambung tinggi ketika ikan sedang langka. Terlihat sangat jelas ketika musim ikan melimpah maka penghasilan yang didapat tidak sebanding dengan jumlah ikan yang dilelang, sebaliknya jika keadaan alam sedang tidak bersahabat maka harga ikan menjadi sangat tinggi tetapi hal ini tidak memberikan pengaruh yang baik berkaitan dengan hasil lelang nelayan karena jumlah ikan yang dijual sedikit.

Dari hal tersebut diatas bakul-bakul ikanlah yang mempermainkan harga ikan dipasaran, sebagai tangan pertama (pembeli) mereka mampu menaikan harga ikan sangat tinggi sehingga jika dikalkulasi laba yang diterima bakul ikan lebih tinggi dibandingkan dengan nelayan.

\section{Cek Mundur}

Pembayaran hasil lelang biasanya tidak dalam bentuk uang tunai melainkan dalam bentuk cek yang dapat dicairkan di bank. Kendala yang dihadapi dilapangan adalah ketika pencairan cek tersebut tidak tepat waktu atau mundur, maka otomatis proses bagi hasil penjualan ikan hasil tangkapan juga ikut tertunda.

Cek mundur terjadi karena keterlambatan pelunasan pembayaran bakul ikan pemenang lelang ke kasir TPI Pelabuhan Kota Pekalongan, hal tersebut terjadi karena proses pemasaran ikan yang dilakukan oleh bakul-bakul ikan ke- 
pada pembeli tangan kedua yang pada umumnya berada diluar kota seperti Bandung, Jakarta Surabaya, dan kota-kota besar lainnya.

Proses jual beli antara bakul ikan dengan pedagang biasanya menggunakan sistem down payment (DP) dimana pedagang membayar separo harga ikan terlebih dahulu setelah terjadi adanya kesepakatan pembelian ikan, yang kemudian pedagang akan melunasi sisa DP setelah ikan tiba ditempat tujuan.

Keadaan tersebut menyebabkan para bakul ikan pemenang lelang menyetorkan uang pembayaran lelang kepada TPI Pelabuhan Kota Pekalongan pada sore hari. Penundaan penyetoran uang oleh bakul ikan tersebut otomatis dapat mengakibatkan penundaan penyetoran uang hasil lelang dari TPI Pelabuhan Kota Pekalongan ke bank.

\section{Aksi Premanisme di TPI}

Premanisme ini dilakukan oleh individual. Pungutan dilakukan dengan meminta uang sebesar antara Rp. 20.000,00 (dua puluh ribu rupiah) - Rp. 50.000,00 (lima puluh ribu rupiah) per 12 (dua belas basket). Atau ada pula yang meminta dalam bentuk ikan sebanyak sekian basket untuk dijual sendiri kebakul ikan.

\section{Semakin Jauhnya fishing ground}

Pada masa kejayaan nelayan masa trip kapal jenis purse seine hanya memakan waktu 1 bulan untuk mencapai target yang telah ditentukan. Sekarang Kapal jenis Purse Seine harus mencapai minimal 2 (dua) hingga 3 (tiga) bulan lebih untuk dapat mencapai target. Hal ini dikarenakan beberapa jalur-jalur kapal yang ditutup dan tidak boleh dilewati karena berkaitan dengan konservasi pengembalian populasi ikan.

\section{Upaya yang dilakukan pemilik Kapal Motor Pelita Jaya di dalam mengurangi kerugian bisnis penangkapan ikan di jalur perairan Selat Makassar}

\section{Transaksi Jual Beli di Laut}

Apabila melihat dari peraturan perundang-undangan maka transaksi jual beli dilaut tersebut tidak diperbolehkan oleh undang- undang hal tersebut berdasarkan pada ketentuan pasal 16 Peraturan Menteri Kelautan dan Perikanan Republik Indonesia Nomor Per.12/MEN/2009 tentang Perubahan Atas Peraturan Menteri Kelautan dan Perikanan Republik Indonesia Nomor PER.05/MEN/2008 tentang Usaha Perikanan Tangkap.

Pelarangan jual-beli di laut juga terdapat berkaitan dengan Otonomi Daerah dimana pelabuhan asal Kapal Motor Pelita Jaya yang tercantum dalam SIPI juga telah menentukan dalam Pasal 2 ayat (3) Peraturan Daerah Kota Pekalongan Nomor 12 Tahun 2009 tentang TPI yang menegaskan semua hasil penangkapan ikan dilaut dari suatu daerah perikanan yang tidak dipergunakan sebagai lauk pauk bagi nelayan harus dijual secara lelang di TPI.

Apabila dalam perjalanan menuju spot penangkapan ikan, palkah telah terisi penuh sedangkan perbekalan masih memadai untuk melanjutkan ke spot-spot penangkapan ikan lainnya. Nakhoda sebagai penanggung jawab atas kapal berdasarkan perintah pemilik melalui pengurus kapal memerintahkan melakukan transaksi jual beli ditengah laut kepada kapal lain jika dalam pertimbangan biaya untuk kembali ke pelabuhan asal membutuhkan biaya yang tinggi dibandingkan perjalanan kapal menuju spot lainnya.

Proses jual beli di laut juga dilakukan apabila dalam keadaan ketika trip akan berakhir atau perbekalan telah menipis, sedangkan jumlah tangkapan ikan sedikit dan apabila dipaksakan untuk melalui proses lelang dikhawatirkan akan membusuk.

Ketika hasil tangkapan ikan sedikit dan harga dipasaran rendah, maka nahkoda lebih memilih untuk menjual ikan ditengah laut dengan harapan mendapatkan hasil penjualan lebih tinggi dibandingkan dengan melalui proses lelang di TPI Pelabuhan Kota Pekalongan.

Keadaan lain yang mengharuskan menjual hasil tangkapan ikannya di laut yaitu ketika dilakukan perbandingan kalkulasi penjualan ikan dengan melalui lelang di TPI Pelabuhan Kota Pekalongan akan mengalami kerugian, sedangkan apabila dilakukan penjualan ikan hasil 
tangkapan ditengah laut mampu menutup modal dan tidak terjadi kerugian.

\section{Menjual ke Pelabuhan Terdekat}

Pasal 14 Peraturan Pemerintah Kelautan dan Kelautan Nomer Per. 05/Men/2008 dinyatakan bahwa setiap orang atau badan hukum Indonesia yang melakukan kegiatan pengangkutan di laut lepas wajib memiliki Surat Izin Kapal Pengangkut Ikan (SIKPI) untuk setiap kapal yang digunakan ayat (2). Pemberian atas izin SIUP dan SIKPI memperhatikan hukum Internasioanal. Kapal berbendera Indonesia mendapat kan SIKPI mematuhi hukum internasioanal dan ketentuan organisasi pengelolaan perikanan regional ayat (4). Ketentuan lebih lanjut mengenai pengoprasiaan kapal pengangkut ikan berbendera Indonesia yang dipergunakan untuk melakukan pengangkutan ikan di laut lepas sebagaimana dimaksud ayat (4) diatur tersendiri dengan peraturan menteri.

Bertitik tolak dari ketentuan dalam Pasal 14 diatas memberikan suatu gambaran bahwa kapal penampung memiliki keistimewaan mampu mempergunakan fasilitas pelabuhan yang kaitannya dengan usaha perikanan tangkap. Terdapat pelarangan dimana kapal penampung dilarang melakukan pengangkutan ikan jika bukan dalam satu armada.

Analisis tersebut diatas maka pengusaha melakukan hubungan Join operasinal seperti yang dilakukan oleh pemilik Kapal Motor Pelita Jaya. Pemilik kapal melakukan join operasinal terhadap beberapa kapal penampung dengan nota kesepakan yang disahkan oleh notaris.

Pasal 15 Peraturan Menteri Kelautan dan Perikanan Nomor Per.05/Men/2008 menyatakan bahwa kapal pengangkut ikan dalam satuan armada penangkapan ikan untuk dibawa ke pelabuhan pangkalan yang tercantum dalam SIKPI ayat (1). Kapal pengangkut ikan dalam satuan armada pengangkutan ikan dilarang mengangkut ikan dari kapal penangkap ikan dan/ atau kapal pengangkut ikan atau yang bukan dalam satu kesatuan menejemen usaha dan/ atau membawa hasil ikan dari daerah penagkapan ke pelabuhan pangkalan yang tidak ter- cantum dalam SIKPI atau langsung ke luar negeri ayat (2). ${ }^{9}$

Nota Kesepakatan yang disahkan melalui notaris adalah cara untuk menyiasati transaksi jual beli di perairan Selat Makassar antara Kapal Motor Pelita Jaya dengan nelayan setempat. Nota kesepakan yang disahkan notaris digunakan sebagai dasar hukum agar Kapal Motor Pelita Jaya tidak terkena sanksi, seolah join operasioanl yang tercantum dalam nota kesepakan adalah pengangkutan atas hasil tangkapan ikan, namun sebenarnya dalam proses pemindahan muatan ikan dari kapal penangkap ikan ke kapal penampung adalah transaksi jula beli yang dilakukan olah antar kapal tersebut. Keistimewaan lain adalah transaksi jual beli yang dilakukan atas dasar nota kesepakan ini kapal yang notabenya milik nelayan lokal membeli harga ikan sesuai dengan harga pasaran sehingga tidak membawa kerugian bagi Kapal Motor Pelita Jaya. Sebaliknya nelayan lokal mampu menekan pengeluaran atas operasional kapal karena tidak perlu melakukan kegiatan penangkapan ikan sendiri. Dalam hal ini kedua belah pihak saling diuntungkan.

\section{Proses Pelelangan Ikan Secara Bertahap}

Hasil tangkapan ikan yang meningkat berakibat pada harga ikan yang rendah, sehingga nelayan menyiasatinya dengan membongkar ikan yang akan dilelang secara bertahap. Apabila dikalkulasi dengan melalui lelang yang bertahap tidak mampu menutup biaya operasional maka Kapal melakukan bongkar ikan sebagian lalu sisanya akan dijual langsung pada pegadang ikan di luar kota dengan harga lebih tinggi dari pada lelang. Sebenarnya proses ini melanggar ketentuan pasal 6 Peraturan daerah nomor 12 tahun 2009 tentang Tempat Pelelangan ikan. Cara ini ditempuh untuk menutup biaya operasional yang tinggi yang telah di keluarkan untuk modal keberangkatan Kapal Motor Pelita Jaya.

\section{Penanggungan Utang Pada Nahkoda Baru}

Berkaitan dengan hal tersebut biasanya pemilik kapal memberikan 2 (dua) kali kesem-

\footnotetext{
9 H. Supriadi \& Alumuddin, Op. Cit, hlm 396.
} 
46 Jurnal Idea Hukum

Vol. 1 No. 1 Edisi Maret 2015

Magister Hukum Fakultas Hukum Universitas Jenderal Soedirman

patan kepada nahkoda untuk kembali melakukan penangkapan ikan berdasarkan trip yang disepakati bersama. Hal tersebut bertujuan untuk menutup kerugian pada trip sebelumnya, apabila dalam kesempatan tersebut nahkoda tetap merugi maka kerugian tersebut akan ditanggungkan kepada nahkoda yang baru.

Ketika nakhoda tidak mampu memenuhi target yang ditentukan kerugian akan ditanggung bersama-sama antara pemilik dan nelayan. Jumlah total perbekalan yang dikeluarkan pemilik sebagai modal awal sebagai contoh sebesar Rp.250.000.000,- (dua ratus lima puluh juta rupiah) lalu hasil lelang mendapatkan raman bersih sebesar Rp. 75.000.000,- (tujuh puluh lima juta rupiah) maka kerugian pada trip sebelumnya akan dibebankan pada trip II, untuk mengganti tenaga nakhoda dan nelayan selama melakukan pekerjaan di laut. Pengusaha memberikan bon pada masing-masing awak kapal yang nantinya bon tersebut diperhitungkan pada bagi hasil ditrip ke II.

Pemberian bon kepada awak kapal atas dasar kesepakatan bersama, pada umumnya pemberian bon untuk nakhoda sebesar Rp. 5.000.000,- (lima juta rupiah) sedangkan bon untuk ABK Pelita Jaya sebesar Rp. 500.000,(lima ratus ribu rupiah). Pada kasus ABK Pelita Jaya yang mengundurkan diri untuk tidak mengikuti trip ke II maka pembebanan bon di tanggung oleh nakhoda dan ABK yang baru. Pada sistem ini penghitungan bon pada trip I diakumulasikan ke dalam perbekalan pada trip ke II. Jika dalam kesempatan ke II nakhoda mengalami kerugian kembali pada umumnya pengusaha akan memutuskan hubungan kerja dan mencari nakhoda yang baru lalu membabankan kerugian pada nahkoda yang baru.

\section{Menjual Ikan pada Perusahaan}

Tingginya retribusi pada Tempat Pelelangan Ikan, pemilik kapal sering kali melakukan penjualan hasil tangkapan ikan kepada perusahaan, karena hasil penjualan pada perusahaan lebih tinggi dibandingkan dengan melalui sistem lelang. Perusahaan membeli hasil tangkapan ikan dengan sistem per kilogram $(\mathrm{Kg})$, sehingga dapat mengurangi biaya pengeluaran untuk retribusi, biaya bongkar, dan sewa basket ikan.

\section{Pengolahan Menjadi Ikan Asin}

Ketika kapal berada di tengah laut dan cuaca tidak memungkinkan untuk melanjutkan perjalanan maka kapal akan bertambat di pulau terdekat, berkaitan dengan membaiknya cuaca waktu bertambat tidak mampu diprediksi seberapa lama Kapal Motor Pelita Jaya akan menambatkan kapalnya di pulau.

Muatan yang berada dipalkah adalah ikan dalam keadaan diawetkan dengan es balok dan garam. Semakin lama ikan diawetkan dalam es maka akan mengalami penurunan kualitas sehingga harga jual akan menurun, sehingga untuk mengurangi kerugian karena penurunan kualitas ikan maka hasil tangkapan biasanya diolah menjadi ikan asin. Ikan-ikan akan diolah menjadi ikan kering dan disimpan hingga tiba waktunya bongkar muat di pelabuhan.

\section{Penutup \\ Simpulan}

Berdasarkan uraian tersebut di atas, maka dapat disimpulkan bahwa: Pertama, prosedur Operasional Kapal Motor Pelita Jaya di dalam menjalankan bisnis perikanan tangkap adalah sebagai berikut: (1) pengurusan dokumen kapal yang meliputi surat hak milik, surat keterangan tukang, gross akte, surat ukur dan PAS tahunan. Dokumen selanjutnya adalah yang terkait dengan izin bisnis penangkapan ikan yang meliputi SIUP, pemeriksaan fisik kapal, rekomendasi SIPI, aktivasi transmitter, VMS, buku lapor pangkalan, surat keterangan radio telekomunikasi, sertifikat kelaikan dan keselamatan awak kapal, dan buku harian (log book). Untuk pengurusan izin keberangkatan kapal meliputi buku Sijil, buku kesehatan, buku langganan bunker pertamina, dan surat tanda lapor kapal keluar dan dokumen yang berada (dibawa) diatas Kapal Motor Pelita Jaya antara lain adalah SIPI, SLO, tanda pelunasan pungutan perikanan, sticker barcode, SIB, dan dokumen lain yaitu buku langganan bunker pertamina dan buku harian (log book); (2) Pengisinan perbekalan untuk mencukupi kebutuhan sehari-hari ketika me- 
laut selama 4-6 bulan berdasarkan atas kesepakatan antara pemilik dan nelayan. Kesepakatan tersebut mengacu pada ketentuan Pasal 1313 KUH Perdata, Pasal 1320 KUH Perdata, dan Pasal 1338 KUH Perdata; (3) Kapal Motor Pelita Jaya melakukan penangkapan ikan sesuai dengan SIPI Kapal Motor Pelita Jaya yaitu di Perairan Laut Jawa dan Selat Makassar; (4) Proses pelelangan ikan dilakasanakan di TPI Pelabuhan Kota Pekalongan dengan mengacu pada ketentuan Undang-undang Nomor 45 tahun 2009 Tentang Perubahan Atas Undang-undang nomor 31 Tahun 2004 Tentang Perikanan, Peraturan Menteri Kelautan dan Perikanan Nomor Per.12/MEN/2009 Tentang Perubahan Atas Peraturan Menteri Kelautan dan Perikanan Nomor Per.05/MEN/2008 tentang Usaha Perikanan Tangkap dan Peraturan Daerah Kota Pekalongan Nomor 12 Tahun 2009 tentang Tempat Pelelangan Ikan. Pada prakteknya proses pelelangan ikan di TPI Pelabungan Kota Pekalongan dinilai memberatkan bagi pemilik kapal dan nelayan. Retribusi yang masuk pada Pemerintah Daerah Kota Pekalongan sebesar $3 \%$ (tiga persen) dimana 1,5\% (satu setengah persen) dikenakan pada bakul ikan dan 1,5\% (satu setengah persen) dikenakan pada nelayan. Selain retribusi, nelayan juga dikenakan iuran wajib sebesar $1,5 \%$ (satu setengah persen) hingga $2 \%$ (dua persen) sesuai kesepakatan antara nelayan dengan pengelola yaitu KUD Makaryo Mino. Total biaya yang dikeluarkan adalah sebesar 3\% (tiga persen) diluar biaya bongkar hasil perikanan dan sewa basket ikan. Selain itu terdapat aksi premanisme yang dilakukan oleh individu dengan meminta uang sebesar Rp.20.000,00 (duapuluh ribu rupiah) hingga Rp.50.000,00 (limapuluh ribu rupiah) per 12 (duabelas) basket ikan; (5) Nelayan menerima hasil penjualan ikan melalui proses lelang selanjutnya dilakukan proses bagi hasil antara pemilik dan nelayan. Proses bagi hasil tersebut mengacu pada Undang-undang Nomor 16 Tahun 1964 Tentang Bagi Hasil Perikanan dan berdasarkan kesepakatan antara pemilik dan ne-layan yang menentukan masing-masing bagian adalah sebanyak 50\%:50\% (limapuluh persen banding limapuluh persen).
Kedua, Kendala yang dihadapi Kapal Motor Pelita Jaya di dalam melakukan bisnis penangkapan ikan yaitu proses perizinan yang rumit dan melewati banyak instansi yang harus ditempuh oleh pemilik Kapal Motor Pelita Jaya, retribusi VMS dan Pelunasan Pungutan Perikanan (PPP) yang tinggi, biaya Docking kapal (bengkel kapal) yang tinggi, modal Usaha yang tinggi, tingginya retribusi ketika proses lelang, kendala lain yang sering dijumpai nelayan dan pengusaha adalah belum adanay patokan harga ikan, cek mundur, aksi premanisme di TPI Pelabuhan Kota Pekalongan, dan semakin jauhnya kawasan penangkapan ikan (fishing ground).

\section{Saran}

Terkait dengan regulasi peraturan perundang-undangan dalam bidang perikanan cukup kompleks, oleh sebab itu haruslah dibarengi dengan pengawasan secara optimal oleh pemerintah. Agar tidak terjadi ketimpangan dimana peraturan perundang-undangan yang ketat dan membutuhkan biaya tinggi malah membawa rasa ketidakadilan kepada setiap pengusaha dibidang perikanan. Mengingat jumlah ikan yang ditangkap oleh nelayan Indonesia lebih kecil dibandingkan dengan jumlah ikan yang dicuri oleh kapal asing disebabkan penggunaan alat tangkap yang lebih canggih.

Pertama, dari segi aparat penegak hukum diperlukan adanya penyerderhanaan alur proses kepengurusan perizinan dan instansi yang berkaitan agar kepengurusan dokumen perizianan tidak memerlukan biaya yang terlalu tinggi. Serta jangka waktu dokumen yang diperpanjang minimal 1 tahun sebagai contoh dokumen perizinan Sertifikat Kelaikan dan Pengawakan Kapal Penangkap Ikan dimana masa berlakunya hanya 11 (sebelas) bulan. Berkaitan Transparasi pembayaran air time yang dibayarkan pemilik kapal setiap tahun tidak pasti dimana tanpa disertai rician biaya dan kewajiban pengaktifan VMS sepanjang tahun memberatkan ketika kapal hanya ditambatkan atau sedang tidak beroperasi. Sebaiknya pemerintah menentukan kebijakan dalam hal penarikan biaya air time ketika kapal beroperasi. 
48 Jurnal Idea Hukum

Vol. 1 No. 1 Edisi Maret 2015

Magister Hukum Fakultas Hukum Universitas Jenderal Soedirman

Kedua, dari segi masyarakat khususnya pemilik kapal dan nelayan harus mampu meningkatkan kesadaran dalam hal ketaatan hukum. Hal tersebut dapat dilakukan dengan cara merubah perilaku pengusaha dalam kepengurusan dokumen yang telah umum menggunakan jasa calo maka perbaikan sistem pelayanan dimulai dari instansi yang melayani administrasi permohonan perizinan yang lebih cepat dalam melakukan pelayanan sehingga dokumen perizinan dapat digunakan tepat pada waktunya yaitu pada saat musim ikan tiba. Berkaitan dengan pengusaha yang kurang taat pada regulasi peraturan perundang-undangan karena menilai terlalu banyak perizinan yang dilewati maka perbaikan kesadaran hukum itu dimulai dengan memberi pengetahuan kepada pengusaha dan nelayan bahwa dari ketidaktaatan akan hukum itu akan membawa kerugian yang lebih besar. Ketika pengusaha dan nelayan melakukan operasional penangakapan ikan tidak memiliki dokumen yang lengkap, maka denda yang dikenankan oleh pemerintah lebih tinggi dari pada biaya kepengurusan izin penangkapan ikan, peran ini dapat dilaksanakan dengan bantuan HNSI Cabang Kota Pekalongan mengingat HNSI Cabang Kota Pekalongan adalah organisasi yang menaungi nelayan dibawah Pelabuhan Perikanan Nusantara Pekalongan.

\section{Daftar Pustaka \\ Buku}

Faesal, Sanapiah. 1990. Penelitian Kualitatif, Dasar-Dasar Dan Aplikasinya. Malang: Yayasan Asi Asah Asuh;

J. Moleong, Lexy. 1991. Metode Penelitian Kualitatif. Bandung: PT. Remaja Risda Karya;

M. Friedman, Lawrence. 2011. Sistem Hukum, Perspektif IImu Sosial. Bandung: Nusa Media;

Muhadjir, Noeng. 1996. Metode Penelitian Kualitatif edisi III, Yogyakarta: Rekasarasin;

Mulyadi. 2002. Akuntansi Biaya, Edisi Ke-5, Yogyakarta: Aditya Media;

Nasir, Moh,. 1999. Metode Penelitian. Jakarta: Ghalia Indonesia;

Rato, Dominikus. 2009. Pengantar Hukum Adat. Yogyakarta: LaksBang Pressindo;
Soekanto, Soerjono. 2010. Pengantar Penelitian Hukum, Jakarta: Universitas Indonesia (UI)-press.

Soerjono. 1978. Pokok-pokok Hukum Adat, Bandung: Alumni;

Sunggono, Bambang. 2003. Metode Penelitian Hukum, Cetakan ke 6. Jakarta: PT Raja Grafindo Persada;

Supriadi, H. \& Alimuddin. 2011. Hukum Perikanan di Indonesia. Jakarta: Sinar Grafi$\mathrm{ka}$;

\section{Peraturan Perundang-Undangan}

Kitab Undang-undang Hukum Perdata (KUH Perdata);

Kitab Undang-undang Hukum Dagang (KUH Dagang);

Undang-undang Nomor 45 Tahun 2009 Tentang Perubahan Atas Undang-undang Nomor 31 Tahun 2004 tentang Perikanan;

Undang-undang Nomor 31 Tahun 2004 tentang Perikanan;

Undang-undang Nomor 9 Tahun 1985 Tentang Perikanan;

Undang-undang Nomor 5 Tahun 1983 tentang Zona Ekonomi Eksklusif Indonesia.

Undang-undang 16 Tahun 1964 Tentang Bagi Hasil Perikanan;

Undang-undang Nomor 17 Tahun 1985 Tentang Pengesahan United Nations Convention On The Law Of The Sea (Konvensi Perserikatan Bangsa-Bangsa Tentang Hukum Laut;

Undang-Undang Nomor 32 Tahun 2004 Tentang Pemerintahan Daerah;

Undang-undang Nomor 17 Tahun 2008 tentang Pelayaran;

Undang-undang Nomor 36 Tahun 1996 Tentang Telekomunikasi;

Undang-undang Nomor 17 Tahun 2008 Tentang Pelayaran;

Keputusan Direktur Jenderal Pengawasan dan Pengendalian Sumberdaya Kelautan dan Perikanan Nomor KEP.043/DJ-P2SDKP/ 2008 Tentang Penggunaan Buku Lapor Pangkalan Bagi Kapal Perikanan.Keputusan Menteri Perhubungan No.KM.41 Tahun 1990 Tentang Pengukuran Kapalkapal Indonesia;

Peraturan Menteri Kelautan dan Perikanan Nomor Per.07/Men/2010 Tentang Surat Laik Operasi Kapal Perikanan; 
Peraturan Menteri Kelautan dan Perikanan Nomor Per.18/Men/2006 Tentang Skala Usaha Pengelolaan Hasil Perikanan;

Peraturan Menteri Perdagangan Nomor 12 Tahun 2010 Tentang Penetapan Harga Patokan Ikan untuk Perhitungan Pungutan Hasil Perikanan;

Peraturan Pemerintah Nomor 16 Tahun 1994 Atas Perubahan Surat Edaran MENPAN Nomor SE/07/M.PAN/2004;

Perda Kota Pekalongan Nomor 12 Tahun 2009 Tentang Tempat Pelelangan Ikan;

Permen Kelautan dan Perikanan No. PER. 07/ MEN/2010 Tentang Surat Laik Operasi Kapal Perikanan;

PerMen Kelautan dan Perikanan Nomor 03/ PerMen-KP/2013 Tentang Kesyahbandaran di Pelabuhan Perikanan;

Permen KP Nomor PER/27/MEN/2009 Tentang Pendaftaran dan Penandaan Kapal Perikanan.

Permen Perikanan dan Kelautan Nomor Per.05/ Men/2007 Tentang Penyelenggaraan Sistem Pemantauan Kapal Perikanan;

PerMenKes No.2348/MENKES/PER/XI/2011 Tentang Perubahan Atas PerMenKes No.356/MENKES/PER/IV/2008 Tentang Organisasi dan Tata Kerja Kantor Kesehatan Pelabuhan;

SK. DIRJEN LA (Direktorat Jenderal Perhubungan Laut) No.PY67/67/1/13-90;

Surat Kepdirjen Pengawasan dan Pengendalian Sumber Daya Kelautan dan Perikanan Nomor Kep.19/DJ-P2SDKP/2008 Tentang Petunjuk Teknis Operasional Pengawasan Kapal Perikanan. 